розроблено два державних стандарти щодо обгрунтування рівнів обслуговування автомобільних доріг при їх експлуатаційному утриманні. Перспективами наукових досліджень $є$ практична апробація наведених розробок та їх вдосконалення з урахуванням потреб галузі та сучасного світового рівня наукових досягнень.

\title{
Література:
}

1. МР В.3.2-02070915-844:2014 Методичні рекомендації з управління станом автомобільних доріг на основі довгострокових контрактів з поточного дрібного ремонту та утримання доріг за показником рівня їх обслуговування. Київ, 2011.35 с.

2. Розробити методику та інформаційно-аналітичну систему управління станом автомобільних доріг на основі довгострокових контрактів з поточного дрібного ремонту та утримання доріг за показником рівня їх обслуговування. Звіт про науково-дослідну роботу № 35-13. № державної реєстрації 0113U001972. Київ, 2013. 135 с.

3. Виконати аналіз та розробити вимоги до усунення дефектів елементів доріг при реалізації довгострокових контрактів 3 поточного дрібного ремонту та експлуатаційного утримання автомобільних доріг загального користування. Звіт про науково-дослідну роботу № 49-15. № державної реєстрації 0115U001651. Київ, 2013. 217 с.

DOI https://doi.org/10.30525/978-9934-588-79-2-2.33

\section{ПРОБЛЕМАТИКА ЗАСТОСУВАННЯ КОНСТРУКЦІЙ УКРІПЛЕННЯ УКОСІВ ЗЕМЛЯНОГО ПОЛОТНА АВТОМОБІЛЬНИХ ДОРІГ}

\author{
Чечуга О. C. \\ кандидат технічних наук, дочент, \\ доиент кафедри транспортного будівництва та управління майном \\ Національного транспортного університету \\ м. Київ, Украӥна
}

Головний ворог земляного полотна - вода. Стійкість зволоженого грунту знижується, тому в залежності від місцевих умов потрібно виконати заходи щодо забезпечення стабільності земляного полотна. До їх числа відносяться:

- регулювання поверхневого стоку; 
- захист земляного полотна від впливу атмосферних факторів;

- зміцнення грунтів.

Регулювання поверхневого стоку потрібно для того, щоб не відбувалися розмиви земляного полотна та інфільтрація поверхневих вод в грунт. Для цього планують територію, прилеглу до земляного полотна, чим забезпечують стік води; створюють мережу водозбірноводовідвідних споруд; приймають спеціальні заходи проти інфільтрації в грунт води з поверхні та через дно та стінки водовідвідних пристроїв.

Для захисту земляного полотна від размивної дії води, прибою хвиль, видування грунтів вітром і шкідливого впливу інших атмосферних чинників застосовують засів травою, одернування, мощення каменем, кам'яні відсипи, бетонні, залізобетонні та асфальтові покриття, деревно-чагарникові насадження. Остаточне рішення в кожному конкретному випадку приймається на основі порівняння варіантів.

При призначенні конструкцій зміцнення враховують додаткові конструктивні заходи по запобіганню земляного полотна від перезволоження та розмиву за рахунок системи поверхневого водовідведення, інших технологічних заходів (ущільнення укісних частин, призначення порядку розробки високих насипів).

Конструкції зміцнення укосів в комплексі з іншими заходами повинні забезпечувати місцеву стійкість укосів протягом усього терміну служби автомобільної дороги.

Тип конструкції зміцнення встановлюють на основі комплексної оцінки грунтових, гідрологічних, кліматичних умов, рельєфу місцевості, конструкції земляного полотна, даних по наявності місцевих будівельних матеріалів. Остаточне рішення за типом зміцнення укосів приймається на основі техніко-економічного зіставлення варіантів.

Призначення конструктивних рішень, часткових вимог до матеріалів конкретних типів укріплень проводять враховуючи в частині призначення окремих елементів укріплень (упори, зворотні фільтри).

За сприйняття тимчасових і постійних навантажень конструкції зміцнення укосів поділяються на такі види:

- захисні (ізолюючі), призначені для захисту (ізоляції) поверхневих шарів укосів від водної, вітрової і температурної ерозії;

- несучі, призначені для компенсації зсувних зусиль в поверхневих шарах грунту укосів при перезволоженні, а також силових впливів паводкових і поверхневих вод при підтоплення.

Без розрахунків на місцеву стійкість призначення конструкцій зміцнення проводять для укосів складених: 
- грунтами I групи (малонебезпечні грунтові умови) за умови дотримання вимог чинних нормативних документів;

- грунтами II групи (небезпечні грунтові умови) с застосуванням додаткових технологічних заходів (недопущення розриву в часі між термінами спорудження укосу і його зміцненням, збільшення норми висіву та підвищення вимог до складу і якості насіння і т.д.).

Залежно від групи грунтів за ступенем небезпеки виникнення порушень місцевої стійкості призначення конструкції зміцнення за результатами розрахунків на місцеву стійкість проводять в наступних випадках:

a) для укосів з грунтів III і IV груп (особливо небезпечних грунтові умови) при можливості зсуву або спливів поверхневого шару під вПливом погодних умов;

б) у випадку загрози виникнення механічної суффозії грунту укосу для неподтопляємих укосів виїмок, складених грунтами III групи в разі виходів водоносних горизонтів на укіс;

в) для укосів, що підтоплюються, при силовому впливі хвильових навантажень при можливості виникнення підмивів підошви укосу або розмивів біля підніжжя схилу;

г) для укосів, що непідтоплюються,(3 грунтів всіх груп) при ймовірності виникнення ерозійних деформацій резюмував від поздовжніх течій води по схилу, вздовж підошви укосу (атмосферні, поверхневі паводкові води при часу їх впливу на укіс менше 20 діб) у випадках:

1) високих схилів (більше 12 м), укосів підвищеної крутості при проектному закладенні ухилу більше необхідного;

2) при тривалому терміні або неможливості проведення укріплювальних робіт.

Деякі конструкції укріплення укосів земляного полотна абсолютно не прийнятні для влаштування на укосах насипів автомобільних доріг, проте випадки влаштування цих конструкцій і їх незадовільного функціонування мають місце.

Вибір і призначення конструкцій укріплення укосів земляного полотна автомобільної дороги можуть, як значно зменшувати несприятливий вплив гідрологічних і гідрогеологічних чинників, так і прискорювати ї негативний вплив на автомобільну дорогу в цілому, що вказує на необхідність ретельного опрацювання всіх можливих варіантів конструкцій укріплення укосів земляного полотна на стадії проектування. 


\title{
Література:
}

1. ДСТУ 3013. Правила контролю за відведенням дощових і снігових стічних вод з територій міст і промислових підприємств. Київ, 1995. $17 \mathrm{c}$.

2. ДБН В.2.3.-4:2015. Автомобільні дороги. Ч. І. Проектування. Ч. ІІ. Будівництво. Київ, 2015. 111 с.

3. ВБН В.2.3-218-171-2003. Споруди транспорту. Спорудження земляного полотна автомобільних доріг. Київ, 2003. 120 с.

4. АД А.2.4-37641918-006:2018. Альбом типових проектних рішень конструкцій земляного полотна автомобільних доріг загального користування. Київ, 2018. 56 с.

5. Славінська О.С., Бубела А.В., Бондаренко Л.П., Чечуга О.С. Прогнозування режиму водовідведення 3 дорожньої конструкції. Автошляховик Украӥни. 2020. № 3. С. 28-36.

DOI https://doi.org/10.30525/978-9934-588-79-2-2.34

\section{ПРО ВАЖЛИВУ ПРОБЛЕМУ - ВІДНОВЛЕННЯ ДЕФОРМОВАНИХ БУДІВЕЛЬНИХ ОБ'ЄКТІВ}

\author{
Юхименко А. I. \\ кандидат технічних наук, \\ доиент кафедри промислового та цивільного будівництва \\ Запорізького національного університету \\ Самченко Р. В. \\ кандидат технічних наук, \\ доцент кафедри промислового та цивільного будівництва \\ Запорізького національного університету \\ м. Запоріжжя, Україна
}

Вступ. У світі існує велика кількість деформованих об'єктів, які відбуваються по різним причинам. Інформаційні джерела [1, с. 186; 2 , с. 13] сповіщають, що дана проблема зростає з кожним роком. Ступінь деформування об'єктів сама різна, так як і їх природа - від об’єктивних факторів до суб'єктивних. Деформації будівель, споруд завдають тяжкі наслідки, як у фізичному і моральному, так і в матеріальному планах. Особливо страждають мешканці житлових будинків, коли деформації починаються із тріщиноутворення і до можливих 